\title{
Adult transgender care: A review for urologists
}

Kate Anderson ${ }^{1}$; Yonah Krakowsky²; Emery Potter ${ }^{2}$; Jill Hudson ${ }^{1}$; Ashley R. Cox ${ }^{1}$

${ }^{1}$ Department of Urology, Dalhousie University, Halifax, NS, Canada; ${ }^{2}$ Department of Surgery, University of Toronto, Toronto, ON, Canada

Cite as: Anderson K, Krakowsky Y, Potter E, et al. Adult transgender care: A review for urologists. Can Urol Assoc J 2021 March 18; Epub ahead of print. http://dx.doi.org/10.5489/cuaj.6949

Published online March 18, 2021

$* * *$

\section{Introduction}

Current population studies estimate that $0.4-1.1 \%$ of adults self-identify as transgender.(1) Transgender non-binary (TGNB) patients seek urologic consultations for a variety of reasons including: surgical procedures related to their gender, post-operative complications, sexual health concerns, or for general urological issues. Despite the likelihood that urologists will have clinical encounters with TGNB patients, a Canadian study found that minimal education in residency is focused on this topic.(2)

The World Professional Association for Transgender Health (WPATH) is an international, multidisciplinary professional association. They put forth a set of evidence and expert opinion-based Standards of Care (SOC) which are viewed as the prevailing clinical guidelines worldwide.(3) The Endocrine Society (ES) also has published guidelines on the Treatment of Gender-Dysphoric/ Gender-Incongruent Persons.(4) The recommendations and guidelines discussed in this article are based on the SOC set forth by WPATH, in addition to those from ES.

The purpose of this narrative review is to act as a reference for urologists to help understand and provide quality urologic care for TGNB patients. We aim to provide pertinent information related to: the transition process, hormonal therapies, surgical interventions and urological issues facing the TGNB population.

\section{Terminology}

TGNB individuals have genders that are not aligned with the sex assigned to them at birth.

Cisgender refers to individuals whose gender identity matches their sex assigned at birth. For the purposes of simplifying the language used in this review (Table 1), we will be referring to people whose birth-assigned sex was female but identify as male as 'transgender men'. People assigned 
male at birth but who identify as female will be referred to as 'transgender women'. It is important for a health care provider to inquire what pronouns patients' use to ensure the appropriate language is used and to establish trust. Pronouns can include "she/her", "he/him", "they/them" and others. Terminology is ever changing. Staying current on trans competent language may lead to improved patient care.

\section{The transition process}

Gender dysphoria/ incongruence is defined as distress that may accompany the incongruence between one's gender identity and one's assigned sex at birth.(5) Transition is a term used to describe the process one might take to express their felt gender identity. Transition may involve, social, medical or surgical elements. Social transition can include aspects such dressing in clothing that reflects their gender identity, name/ pronoun change, and changing government identification. Social transitioning alone may alleviate distress from gender dysphoria with improved quality of life and well-being. (6) Medical transition generally refers to starting hormone therapies. Surgical transition can include many possible surgeries to alter one's primary and secondary sex characteristics. There is not one way that a TGNB individual transitions. The process is individualized. For many TGNB patients, social, medical and surgical transition can greatly improve gender dysphoria.(7)

In Ontario, the TransPULSE study surveyed 433 participants regarding the transition process.(8) Of those surveyed, 30\% had not undertaken any steps in the transition process, while $23 \%$ were living in their felt gender but without any medical intervention. Forty-six percent of transgender women and 39\% of transgender men were currently using hormones for a medical transition. Twenty-three percent reported having completely transitioned, which was self-defined and could include medical or surgical measures. Of surgical interventions, orchiectomy was most common, reported by $21 \%$ of transgender women. Vaginoplasty was reported in $15 \%$ of transgender women. In contrast, only $0.4 \%$ of transgender men had undergone phalloplasty. The study confirmed this population represents a heterogeneous group in terms of accessing different aspects of transition. This study also suggested that we may be at the 'tip of the iceberg' in terms of the numbers of patients going through this process.

\section{Hormonal and medical therapies}

Many patients choose to pursue medical treatments to address their gender dysphoria. Hormonal therapy is generally overseen by the patient's primary care provider or endocrinologist.

Hormonal modulation has quality of life benefits for transgender patients. $(9,10)$ Criteria for the prescription of hormone therapy includes: gender incongruence, capacity to make informed decisions, and reasonable control of associated mental health conditions.(11)

For transgender men, masculinizing hormonal treatment is primarily exogenous testosterone therapy. Transdermal, subcutaneous and intramuscular (IM) formulations are most 
commonly used.(4) Target testosterone levels are the same as for cisgender males of the same age. Patients should be screened for contraindications to testosterone therapy including: pregnancy, unstable coronary artery disease, and untreated polycythemia.(12) Patients with a history of estrogen sensitive malignancy may require a referral to oncology due to the potential for testosterone to be converted to estrogen through aromatization. In addition, patients with underlying PCOS may need further evaluation due to an elevated risk of side effects with testosterone. Transgender men at risk of becoming pregnant also require effective birth control measures due to the potential teratogenicity of testosterone.

Masculinizing changes on testosterone therapy include: increased facial/body hair growth, voice deepening, increased muscle mass, reduced fertility, atrophy of breast tissue, cessation of menses, weight gain, increased libido, possible clitoral virilization and vaginal atrophy. Hormonal changes occur over variable time frames and to varying degrees. Like any medical therapy, there are potential risks associated with the use of masculinizing hormone therapy (Table 2).

For transgender women, feminizing hormonal therapy requires both estrogen for feminization and an anti-androgen to suppress testosterone levels.(4) Exogenous estrogen works via a central feedback mechanism to reduce androgen production. It may be delivered through a transdermal patch, oral, and intramuscularly. Oral and intramuscular estrogen therapy, as well as higher estrogen doses, may lead to a higher risk of venous thromboembolic events (VTE).(4) Ethinyl estrodiol oral therapy carries a high risk of VTE and should not be used. Transdermal estrogen in preferable due to side effect profile, but is costly.

The goals of feminizing hormonal therapy include reducing growth of facial hair, skin softening, inducing breast development and promoting fat and muscle redistribution.(11) Erectile dysfunction, testicular atrophy and infertility may occur. Hormonal therapy is guided by the normal physiological range of cisgender women and may take 6-18 mos. Patients must be screened for contraindications to estrogen therapy including: previous VTE related to a hypercoagulable state, previous hormone sensitive neoplasm or end-stage chronic liver disease.

Due to the potential for side effects and to potentiate the effects of estrogen, estrogen is typically used in combination with antiandrogens to minimize the require amount of estrogen to achieve feminizing effects. GnRH agonists are thought to be as effective as other antiandrogens with possibly lower side effects, but cost is prohibitive. $(13,14)$ In Canada, spironolactone and cyproterone acetate (Androcur) are commonly used. Spironolactone works via blockage of the androgen receptor and decreases testosterone levels while cyproterone acetate works by both central and peripheral inhibition. Spironolactone is often prescribed at much higher doses than what is used for hypertension and patients must be monitored for hyperkalemia. Cyproterone acetate carries concerns regarding hepatotoxicity.(15) 5-alpha reductase inhibitors, such as 
finasteride and dutasteride, are typically not necessary as the testosterone levels are almost fully suppressed with estrogen and an antiestrogen.

Patients on hormonal therapy require ongoing follow-up including physical examination and laboratory investigations to assess for hormonal effects and potential complications of treatment. Goals of hormonal manipulation should be to maintain the physiologic level required to meet the patient's desired gender expression.

\section{Transition related genitourinary surgery}

Gender affirming surgical therapies are summarized in Table 3. Surgery can be a crucial step in alleviating gender dysphoria. There is an accumulation of data that outcomes are overtly positive for improving gender dysphoria, as well as quality of life.(16)

The WPATH SOC has several criteria for patients seeking any genital surgery. Patients undergoing reproductive organ surgery (orchiectomy, hysterectomy, oophorectomy) must have two referral letters to the surgeon and have completed at least one year of hormonal therapy. In general, the writer of the referral letter must be a medical doctor, nurse practitioner or Masters level social worker with an interest or prior training in providing transgender healthcare. Provinces may vary in terms of specific requirements for who is eligible to write the referral. The required content of the referral letter is described in Table 4 . The same is recommended before undergoing genital surgery such as metoidioplasty, phalloplasty, or vaginoplasty. However, it is also recommended that these patients demonstrate 12 continuous months of living in a gender role that is congruent with their gender identity prior to surgery.

\section{Orchiectomy}

The benefits of bilateral orchiectomy for transgender women include: the ability to discontinue anti-androgen medication and its associated costs, occasional reduction in estrogen dose, increased ability to 'tuck' and increased ease of wearing gender-congruent clothing. Surgery generally involves a single, median raphe incision and removal of both testicles.(17) If vaginoplasty is intended, preservation of the paragonadal fat pad, dartos fascia and scrotal skin is important for future reconstruction. Patients should be informed of the potential risks of bleeding/ hematoma, infection, permanent infertility, worsening erectile dysfunction, poor cosmesis, and palpable cord stump. Patients may opt for an inguinal, or subinguinal, approach to remove more of the spermatic cord which, if left, may be bothersome. As a dose reduction in hormone therapy may be required post operatively, communication with the health-care provider prescribing hormones is important. 


\section{Vaginoplasty}

Penile inversion vaginoplasty (PIV) is the most common technique performed.(18) In brief, the penile skin and prepuce are used to create a neovaginal cavity. A neovagina is created between the rectum and the urethra. Following scrotectomy and orchiectomy, the remaining skin is used to create labial folds, while the glans penis is reconstructed to form the neoclitoris. The corporal cavernosal tissue is removed as proximally as possible. The prostate is not removed in order to minimize complications. (Figure 1) (19) More involved operations may include intestinal or peritoneal vaginoplasty which allow for the creation of a self-lubricating neovagina. Permanent hair removal (laser/electrolysis) to the scrotum and penile shaft is encouraged to prevent hair growth in the vaginal canal post operatively. Some patients may also choose to pursue zerodepth vaginoplasty/ vulvoplasty. This obviates the need to dilate and avoids the risk of fistula. Vulvoplasty refers to the creation of a clitoris, clitoral hooding, labia minora and majora.

There are many potential long-term issues following vaginoplasty as shown in Table 5.(20) There is a large range of complication rates reported in the literature. Neovaginal stenosis (1.2- 43\%) and wound dehiscence appear to be the most common complications (12-33\%)(20) following penile inversion therapy. As this surgery is only offered in few centres in Canada, long-term post-operative follow-up is challenging.

\section{Metoidioplasty and phalloplasty}

There are several goals to consider when approaching genital surgery for transgender men. Functional goals include gaining the ability to stand to void, consolidation of sexual sensation to the neophallus, and ability to achieve an erection satisfactory for penetrative intercourse.

Metoidioplasty utilizes the virilized clitoral body to create a small phallus, in order to masculinize the phallus while avoiding the morbidity associated with a phalloplasty. Vaginectomy may be performed. During the procedure, the clitoris is degloved and the suspensory ligament divided. The urethra is lengthened using a combination of labia minora and anterior vaginal wall flaps in addition to buccal mucosa. Patients may gain the ability to stand to void via the phallus. The labia majora may be used to create a neoscrotum. (21) Testicular implants may also be placed.

Advantages of metoidioplasty include decreased average number of procedures required, good erogenous sensation consolidation to the neophallus, and lower rates of complications compared to phalloplasty.(22) Common urologic complaints following metoidioplasty are described in Table 5. Urethrocutaneous fistula occurs in 5-23\% of cases (23), with approximately $50 \%$ of these requiring surgical repair. Since the neophallus length is usually only $5-7 \mathrm{~cm}$, penetrative intercourse may be unachievable following metoidioplasty.(24)

Phalloplasty is a complicated, often multi-stage, operation where a flap (usually free flap), is raised to create a neophallus and provide urethral lengthening. There are many different techniques employed based on individual patient needs.(25) One well-studied example is the 
radial artery forearm free flap.(Figure 2) (26) This technique employs a tube-within-a-tube design for formation of the neo-urethra and a neo-phallus large enough to accommodate an erectile prosthesis during a subsequent surgery. The overall complication rate for phalloplasty is high, estimated between 40-70\%.(27) Common complications are described in Table 5.

Complications requiring further surgical reconstruction occurs in approximately $25 \%$ of patients following phalloplasty.(28) Urethrocutaneous fistulas frequently occur (18-78\%) and more than half require surgical revision.(22) Prosthetic erectile implants carry a higher complication rate than in cisgender men with a $12 \%$ infection rate reported in one large study.(29) As well, the flap donor site deformity is an unavoidable downside for this surgery. Phalloplasty (with penile prosthesis) offers a higher likelihood of successful penetrative intercourse and the capacity to stand to void post-operatively. Advantages must be weighed against the longer cumulative surgery and recovery time, and the potential complications. Scrotoplasty with staged placement of testicular implants typically accompanies both metoidioplasty and phalloplasty in transgender men.

Despite the need for multiple surgeries, risk of post-operative complications and potential costs, patients seldom report regret following gender-affirming surgery.(30)

\section{Urologic issues in transgender patients}

\section{Urological malignancy}

Little is known about reproductive malignancies in the transgender population.(31) A retrospective analysis of the North American Association of Central Cancer Registries (NAACR) database between 1995-2013 assessed gender minority cancer patients. Nash et al. found a lower proportional incidence ratio of prostate and testicular malignancies for transgender females compared to similar aged cisgender men.(32) A large retrospective study of 2306 transgender females reported a prostate cancer prevalence of only $0.04 \%$.(33) Transgender women have castrate levels of testosterone and prostate specific antigen (PSA) values need to be interpreted with that in mind. Overall, there is a lack of literature regarding the diagnosis, management and follow-up of prostate cancer in transgender women.

As the transgender patient population increases, prostate cancer in this population will become a more common urological scenario. Experts recommend to follow the same screening protocols as for cisgender men.(34) It is unclear how prolonged estrogen and antiandrogen therapy affect prostate cancer risk. In addition, previous GAS may impact the ability to examine the prostate which may need to be done via examination of the anterior wall of the neovagina.

Testicular cancer is a rare malignancy. Review of the literature found only three case reports of testicular cancer in transgender women on hormonal therapy.(35-37) As with cisgendered men, self-examination should be encouraged, and imaging requested if there are any worrisome lesions especially prior to GAS as the presence of a testicular mass will alter one's 
approach to orchiectomy. It is important for urologists to be aware of several barriers to care in this complex patient population to ensure the diagnosis of urological malignancies are not missed.(33)

\section{Fertility}

Hormonal and surgical therapies for gender dysphoria have obvious deleterious effects on fertility. Yet, many individuals desire to have genetically related children. Reproductive options should be discussed prior to initiating the transition process.(38) It is imperative that both transgender men and women are counselled on fertility options prior to commencing hormonal or surgical therapies.

For transgender men, options include oocyte or embryo freezing prior to hormonal therapy or surgery. Ideally, this would be completed prior to starting masculinizing hormones. However, there is evidence that ovarian function may recover after exposure to testosterone.(39) The success of this is likely dependent on patient age and length of time on testosterone. In addition, successful pregnancies using assisted reproductive techniques (ART) are possible following cessation of hormone therapies.(40) Some transgender men may want to become pregnant even after having transitioned socially or medically.(41) Literature is emerging on the outcomes of ART for transgender men.

It is important to note that although testosterone may alter ovarian function in transgender men, it is not a form of contraception. For patients who do not want to conceive, they should be counselled on the importance of contraception.(41)

Transgender women should be counselled on the role of sperm banking prior to starting hormone therapy. Some evidence suggests that even prior to hormonal therapy, some transgender women have abnormal semen parameters in comparison to fertile cisgender men.(42) Certainly following hormonal therapy, decreased spermatogenesis and fertility occurs. However, cessation of hormone therapy (mean discontinuation period 4.4 months), may allow for recovery of semen parameters comparable to hormone naive transgender women.(43) One post-orchiectomy study on 135 transgender women who had been treated with hormonal therapy found that nearly $80 \%$ had negligible spermatogenesis.(44) Patients must be counselled regarding the irreversibility of infertility following orchiectomy. Little data exists reporting outcomes of ART for transgender women who have chosen sperm cryopreservation.

Prior to transitioning medically or surgically, patients should be advised on the costs associated with sperm/ oocyte cryopreservation and made aware that ART is costly and may not be widely available.

\section{Urinary function}

Transgender patients may present to urology due to lower urinary tract symptoms for multiple reasons including complications of GAS. Following GAS, transgender females may develop 
storage or voiding symptoms related to meatal stenosis or urethral strictures.(28) Incontinence may be a result of urinary retention, stress incontinence, urgency incontinence or potentially fistula formation. During vaginoplasty, dissection between the rectum and bladder may impact the autonomous nerve supply to the bladder leading to lower urinary tract dysfunction.(20) Transgender patients may also experience urinary tract infections following reconstructive surgery.

Following phalloplasty in transgender men the rate of urethral strictures is high ranging from $25-58 \%$.(45) The most common site of stricture formation is the anastomosis between the native and neourethra, as well as the meatus. Post void dribbling may occur due to a lack of bulbospongiosus muscle and corpora spongiosum surrounding the neourethra.(46) Urinary tract infections may also occur following genitourinary reconstruction in transgender men.

A full surgical history should be obtained to narrow the differential diagnosis based on associated common complications. Physical exam and measurement of postvoid residual volumes should be completed. If indicated, cystoscopy may need to be performed with sedation or general anesthetic in some patients with gender dysphoria. Caution should be used when navigating the urethra due the high rate of urethral complications in both transgender men and women following GAS. In the case of acute urinary retention placement of a foley catheter or suprapubic catheter, if necessary, is appropriate. Contacting the patient's GAS surgeon to seek direction for further care may be required. If need be, patients should be referred back to the surgeon who performed the GAS, or to a reconstructive urologist comfortable with complex anatomy.

\section{Conclusions}

The TGNB population represents a growing, heterogeneous group of patients. The transition process may or may not include social changes, hormonal therapy and/or surgery to alter primary and secondary sex characteristics. Transgender patients may be referred to urologists for reasons including: surgical procedures related to their gender transition, post-operative complications, sexual health concerns, or for other general urological issues. Despite a deficiency in formalized training during residency and lack of specialized surgical centres in Canada, urologists must be well versed in transgender healthcare when it comes to urological issues. Urologists have a responsibility to accept patient referrals and provide support. This will allow optimal urologic care of this patient population. 


\section{References}

1. Arcelus J, Bouman WP, Van Den Noortgate W, Claes L, Witcomb G, Fernandez-Aranda F. Systematic review and meta-analysis of prevalence studies in transsexualism. Eur Psychiatry. 2015;30(6):807-15.

2. Coutin A, Wright S, Li C, Fung R. Missed opportunities: are residents prepared to care for transgender patients? A study of family medicine, psychiatry, endocrinology, and urology residents. Can Med Educ J. 2018;9(3):e41-e55.

3. [Available from: https://www.wpath.org/publications/soc.

4. Hembree WC, Cohen-Kettenis PT, Gooren L, Hannema SE, Meyer WJ, Murad MH, et al. Endocrine Treatment of Gender-Dysphoric/Gender-Incongruent Persons: An Endocrine Society Clinical Practice Guideline. J Clin Endocrinol Metab. 2017;102(11):3869-903.

5. 2020 [Available from: https://www.psychiatry.org/patients-families/genderdysphoria/what-is-gender-dysphoria.

6. Russell ST, Pollitt AM, Li G, Grossman AH. Chosen Name Use Is Linked to Reduced Depressive Symptoms, Suicidal Ideation, and Suicidal Behavior Among Transgender Youth. J Adolesc Health. 2018;63(4):503-5.

7. Winter S, Diamond M, Green J, Karasic D, Reed T, Whittle S, et al. Transgender people: health at the margins of society. Lancet. 2016;388(10042):390-400.

8. Scheim AI, Bauer GR. Sex and gender diversity among transgender persons in Ontario, Canada: results from a respondent-driven sampling survey. J Sex Res. 2015;52(1):1-14.

9. Costantino A, Cerpolini S, Alvisi S, Morselli PG, Venturoli S, Meriggiola MC. A prospective study on sexual function and mood in female-to-male transsexuals during testosterone administration and after sex reassignment surgery. J Sex Marital Ther. 2013;39(4):321-35.

10. Gorin-Lazard A, Baumstarck K, Boyer L, Maquigneau A, Gebleux S, Penochet JC, et al. Is hormonal therapy associated with better quality of life in transsexuals? A crosssectional study. J Sex Med. 2012;9(2):531-41.

11. Safer JD, Tangpricha V. Care of Transgender Persons. N Engl J Med. 2019;381(25):2451-60.

12. Carnegie C. Diagnosis of hypogonadism: clinical assessments and laboratory tests. Rev Urol. 2004;6 Suppl 6:S3-8.

13. Dittrich R, Binder H, Cupisti S, Hoffmann I, Beckmann MW, Mueller A. Endocrine treatment of male-to-female transsexuals using gonadotropin-releasing hormone agonist. Exp Clin Endocrinol Diabetes. 2005;113(10):586-92.

14. Gava G, Cerpolini S, Martelli V, Battista G, Seracchioli R, Meriggiola MC. Cyproterone acetate vs leuprolide acetate in combination with transdermal oestradiol in transwomen: a comparison of safety and effectiveness. Clin Endocrinol (Oxf). 2016;85(2):239-46.

15. De Cuypere G, T'Sjoen G, Beerten R, Selvaggi G, De Sutter P, Hoebeke P, et al. Sexual and physical health after sex reassignment surgery. Arch Sex Behav. 2005;34(6):679-90.

16. Murad MH, Elamin MB, Garcia MZ, Mullan RJ, Murad A, Erwin PJ, et al. Hormonal therapy and sex reassignment: a systematic review and meta-analysis of quality of life and psychosocial outcomes. Clin Endocrinol (Oxf). 2010;72(2):214-31. 
17. Francis C, Grober E, Potter E, Blodgett N, Krakowsky Y. A Simple Guide for Simple Orchiectomy in Transition-Related Surgeries. Sex Med Rev. 2020;8(3):492-6.

18. Massie JP, Morrison SD, Van Maasdam J, Satterwhite T. Predictors of Patient Satisfaction and Postoperative Complications in Penile Inversion Vaginoplasty. Plast Reconstr Surg. 2018;141(6):911e-21e.

19. Chen ML, Reyblat P, Poh MM, Chi AC. Overview of surgical techniques in genderaffirming genital surgery. Transl Androl Urol. 2019;8(3):191-208.

20. Horbach SE, Bouman MB, Smit JM, Ozer M, Buncamper ME, Mullender MG. Outcome of Vaginoplasty in Male-to-Female Transgenders: A Systematic Review of Surgical Techniques. J Sex Med. 2015;12(6):1499-512.

21. Lin-Brande M, Clennon E, Sajadi KP, Djordjevic ML, Dy GW, Dugi D. Metoidioplasty With Urethral Lengthening: A Stepwise Approach. Urology. 2020.

22. Djordjevic ML. Novel surgical techniques in female to male gender confirming surgery. Transl Androl Urol. 2018;7(4):628-38.

23. Djordjevic ML, Stojanovic B, Bizic M. Metoidioplasty: techniques and outcomes. Transl Androl Urol. 2019;8(3):248-53.

24. Perovic SV, Djordjevic ML. Metoidioplasty: a variant of phalloplasty in female transsexuals. BJU Int. 2003;92(9):981-5.

25. Heston AL, Esmonde NO, Dugi DD, 3rd, Berli JU. Phalloplasty: techniques and outcomes. Transl Androl Urol. 2019;8(3):254-65.

26. Doornaert M, Hoebeke P, Ceulemans P, T'Sjoen G, Heylens G, Monstrey S. Penile reconstruction with the radial forearm flap: an update. Handchir Mikrochir Plast Chir. 2011;43(4):208-14.

27. Wroblewski P, Gustafsson J, Selvaggi G. Sex reassignment surgery for transsexuals. Curr Opin Endocrinol Diabetes Obes. 2013;20(6):570-4.

28. Gaither TW, Awad MA, Osterberg EC, Murphy GP, Romero A, Bowers ML, et al. Postoperative Complications following Primary Penile Inversion Vaginoplasty among 330 Male-to-Female Transgender Patients. J Urol. 2018;199(3):760-5.

29. Hoebeke PB, Decaestecker K, Beysens M, Opdenakker Y, Lumen N, Monstrey SM. Erectile implants in female-to-male transsexuals: our experience in 129 patients. Eur Urol. 2010;57(2):334-40.

30. van de Grift TC, Elaut E, Cerwenka SC, Cohen-Kettenis PT, Kreukels BPC. Surgical Satisfaction, Quality of Life, and Their Association After Gender-Affirming Surgery: A Follow-up Study. J Sex Marital Ther. 2018;44(2):138-48.

31. Joint R, Chen ZE, Cameron S. Breast and reproductive cancers in the transgender population: a systematic review. BJOG. 2018;125(12):1505-12.

32. Nash R, Ward KC, Jemal A, Sandberg DE, Tangpricha V, Goodman M. Frequency and distribution of primary site among gender minority cancer patients: An analysis of U.S. national surveillance data. Cancer Epidemiol. 2018;54:1-6.

33. Gooren L, Morgentaler A. Prostate cancer incidence in orchidectomised male-to-female transsexual persons treated with oestrogens. Andrologia. 2014;46(10):1156-60.

34. Ingham MD, Lee RJ, MacDermed D, Olumi AF. Prostate cancer in transgender women. Urol Oncol. 2018;36(12):518-25. 
35. Kobori Y, Suzuki K, Iwahata T, Shin T, Sato R, Nishio K, et al. Mature Testicular Teratoma with Positive Estrogen Receptor Beta Expression in a Transgendered Individual on Cross-Sex Hormonal Therapy: A Case Report. LGBT Health. 2015;2(1):81-3.

36. Chandhoke G, Shayegan B, Hotte SJ. Exogenous estrogen therapy, testicular cancer, and the male to female transgender population: a case report. J Med Case Rep. 2018;12(1):373.

37. Wolf-Gould CS, Wolf-Gould CH. A Transgender Woman with Testicular Cancer: A New Twist on an Old Problem. LGBT Health. 2016;3(1):90-5.

38. Riggs DW, Bartholomaeus C. Fertility preservation decision making amongst Australian transgender and non-binary adults. Reprod Health. 2018;15(1):181.

39. Hunter MH, Sterrett JJ. Polycystic ovary syndrome: it's not just infertility. Am Fam Physician. 2000;62(5):1079-88, 90.

40. Adeleye AJ, Cedars MI, Smith J, Mok-Lin E. Ovarian stimulation for fertility preservation or family building in a cohort of transgender men. J Assist Reprod Genet. 2019;36(10):2155-61.

41. Light AD, Obedin-Maliver J, Sevelius JM, Kerns JL. Transgender men who experienced pregnancy after female-to-male gender transitioning. Obstet Gynecol. 2014;124(6):11207.

42. Marsh C, McCracken M, Gray M, Nangia A, Gay J, Roby KF. Low total motile sperm in transgender women seeking hormone therapy. J Assist Reprod Genet. 2019;36(8):163948.

43. Adeleye AJ, Reid G, Kao CN, Mok-Lin E, Smith JF. Semen Parameters Among Transgender Women With a History of Hormonal Treatment. Urology. 2019;124:136-41.

44. Kent MA, Winoker JS, Grotas AB. Effects of Feminizing Hormones on Sperm Production and Malignant Changes: Microscopic Examination of Post Orchiectomy Specimens in Transwomen. Urology. 2018;121:93-6.

45. Nikolavsky D, Yamaguchi Y, Levine JP, Zhao LC. Urologic Sequelae Following Phalloplasty in Transgendered Patients. Urol Clin North Am. 2017;44(1):113-25.

46. Middleton I, Holden FA. Urological issues following gender reassignment surgery. Br J Nurs. 2017;26(18):S28-S33. 


\section{Figures and Tables}

Fig.1. Penile inversion vaginoplasty. Copyright $(\mathrm{C} 2019$ Massachusetts Medical Society. Reprinted with permission from Massachusetts Medical Society. ${ }^{11}$

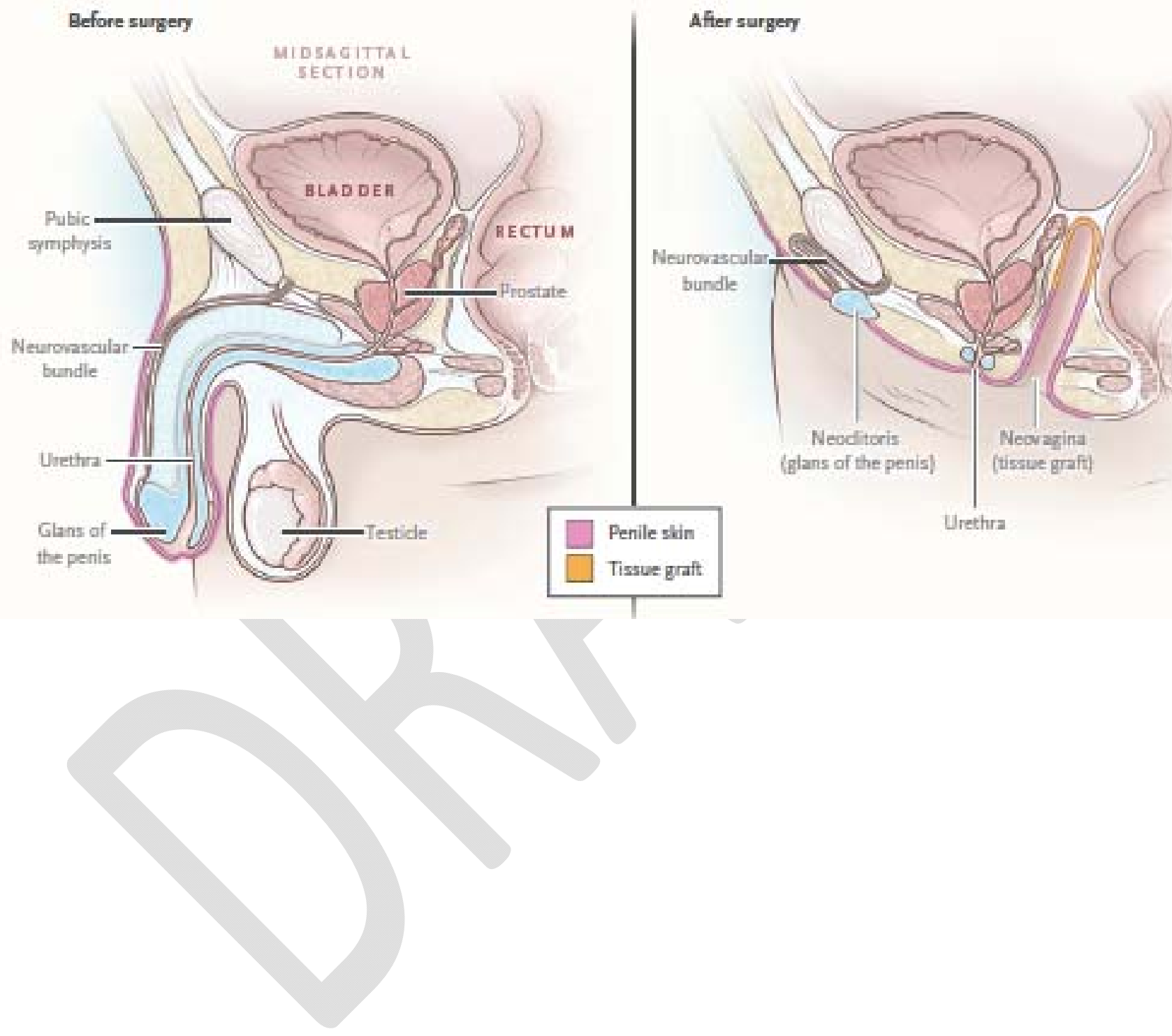

Fig. 2. Phalloplasty. Copyright $(2019$ Massachusetts Medical Society. Reprinted with permission from Massachusetts Medical Society. ${ }^{11}$ 


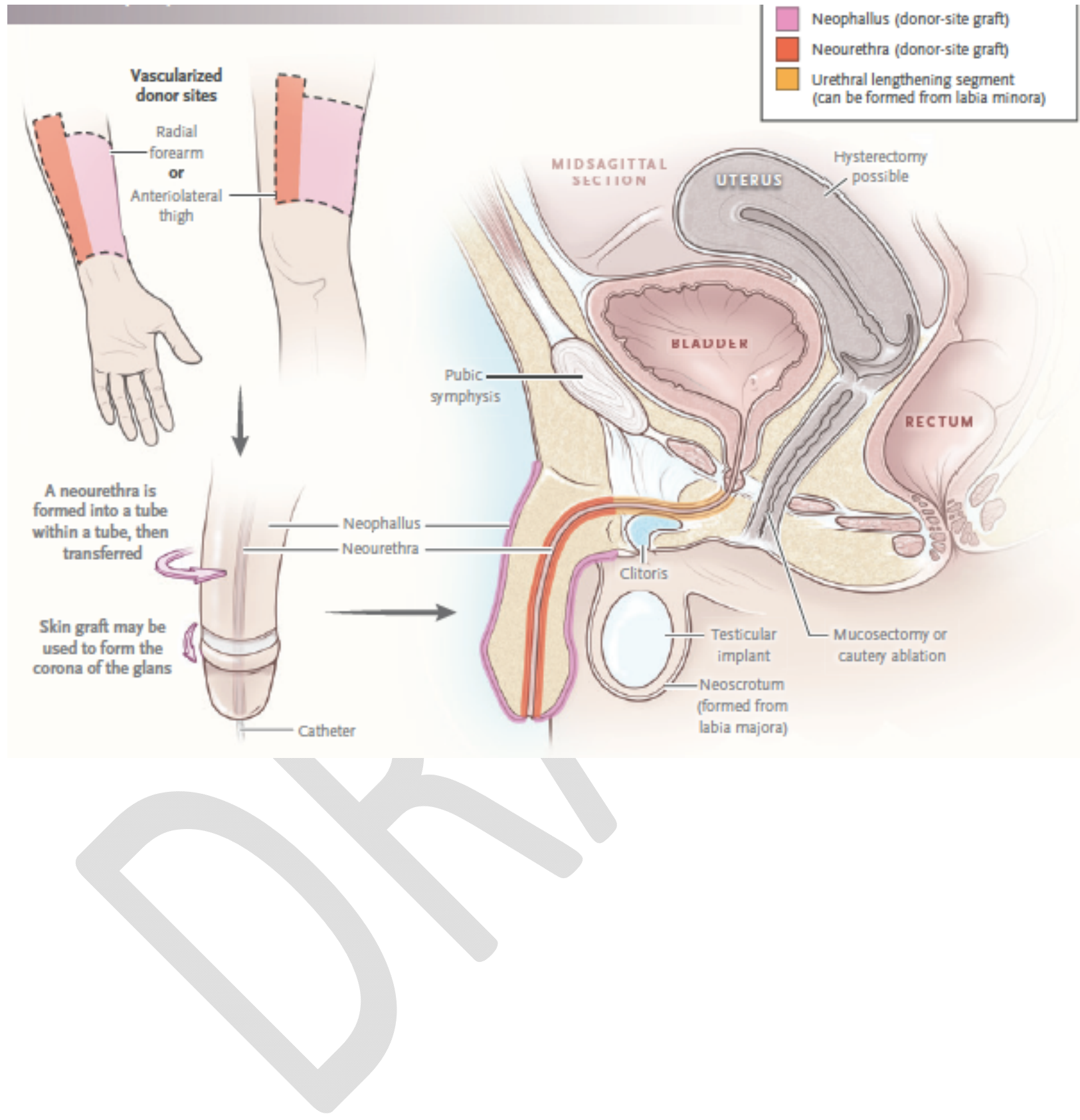




\begin{tabular}{|c|c|}
\hline Term & Definition \\
\hline Natal sex & A person's anatomic assigned sex at birth \\
\hline Gender identity & $\begin{array}{l}\text { One's internal sense of having a particular gender, which may or may } \\
\text { not correspond to their sex assigned at birth. Many have a binary gender } \\
\text { identity and feel that they are either a boy/man or a girl/woman. Others } \\
\text { feel that their gender is on a spectrum and do not identify at one end of } \\
\text { the gender binary }\end{array}$ \\
\hline Cisgender & When one's natal sex and gender identity are congruent \\
\hline Transgender & A person's gender identity and natal sex are discordant \\
\hline $\begin{array}{l}\text { Gender dysphoria/Gender } \\
\text { incongruence }\end{array}$ & $\begin{array}{l}\text { The distress that may accompany the incongruence between one's } \\
\text { gender identity and one's assigned sex (American Psychiatric } \\
\text { Association, 2013) }\end{array}$ \\
\hline Sexual orientation & $\begin{array}{l}\text { Refers to sexual attraction to particular gender(s) regardless of gender } \\
\text { identity, i.e., homosexual, bisexual, asexual, pansexual, heterosexual }\end{array}$ \\
\hline $\begin{array}{l}\text { Gender affirmation } \\
\text { surgery (GAS)/gender } \\
\text { reconstruction surgery } \\
(\mathrm{GRS}) \text { /sex reassignment } \\
\text { surgery (SRS)/Transition } \\
\text { related surgery (TRS) }\end{array}$ & $\begin{array}{l}\text { Surgery performed to change one's primary or secondary sex } \\
\text { characteristics to that of one's gender identity }\end{array}$ \\
\hline
\end{tabular}




\begin{tabular}{|c|c|c|c|}
\hline Name & Indication & Mechanism & $\begin{array}{l}\text { Possible side effects/ } \\
\text { contraindications }\end{array}$ \\
\hline Testosterone & Masculinization & & $\begin{array}{l}\text { Polycythemia, weight gain, acne, } \\
\text { balding, sleep apnea, liver } \\
\text { dysfunction, hyperlipidemia, } \\
\text { worsening mental health } \\
\text { disorders, CAD, CVD, } \\
\text { hypertension, type II diabetes, } \\
\text { changes in bone density, breast or } \\
\text { uterine cancer, cervical cancer, } \\
\text { ovarian cancer }\end{array}$ \\
\hline Spironolactone & Antiandrogen & $\mathrm{K}+$ sparing diuretic & Hypotension, hyperkalemia \\
\hline $\begin{array}{l}\text { Cyproterone } \\
\text { acetate }\end{array}$ & Antiandrogen & GnRH agonist & $\begin{array}{l}\text { prolactinoma (when used with } \\
\text { Estrogen) }{ }^{11} \text { hepatotoxicity }\end{array}$ \\
\hline $\begin{array}{l}\text { Exogenous } \\
\text { estrogen }\end{array}$ & Feminization & $\begin{array}{l}\text { Suppress androgen } \\
\text { production via } \\
\text { central feedback }\end{array}$ & $\begin{array}{l}\text { Side effect: thromboembolic } \\
\text { event, macroprolactinoma, } \\
\text { CVD, cholelithiasis, elevated } \\
\text { liver enzymes, hypertension, } \\
\text { hypertriglycerides, type II } \\
\text { diabetes, weight gain, breast } \\
\text { cancer }{ }^{1,2} \\
\text { Contraindication: breast ca, } \\
\text { previous DVT/PE, cardiovascular } \\
\text { or cerebrovascular disease }\end{array}$ \\
\hline
\end{tabular}

CAD: coronary artery disease; CVD: cardiovascular disease; DVT: deep venous thrombosis; GnRH: gonadotropin-releasing hormone; PE: pulmonary embolism. 


\begin{tabular}{|c|c|c|}
\hline & Transgender men & Transgender female \\
\hline Breast/chest surgery & Subcutaneous mastectomy & Augmentation mammoplasty \\
\hline $\begin{array}{l}\text { Surgery of the } \\
\text { reproductive organs and } \\
\text { genitals }\end{array}$ & $\begin{array}{l}\text { Total or subtotal hysterectomy/ } \\
\text { salpingo-oophorectomy } \\
\text { Vaginectomy } \\
\text { Metoidioplasty with or without } \\
\text { urethral reconstruction, typically } \\
\text { with scrotoplasty with testicular } \\
\text { prosthesis } \\
\text { Phalloplasty (most commonly a } \\
\text { forearm free flap but can also be } \\
\text { pedicle flap) typically with } \\
\text { urethral reconstruction, } \\
\text { scrotoplasty with testicular } \\
\text { prosthesis/ possible penile implant }\end{array}$ & $\begin{array}{l}\text { Orchiectomy } \\
\text { Vaginoplasty (creation of a vaginal } \\
\text { vault lined commonly with scrotal } \\
\text { skin but may also use a section of } \\
\text { colon or peritoneum) } \\
\text { Vulvoplasty including the creation of } \\
\text { a clitoris, clitoral hooding, labia } \\
\text { minora and majora }\end{array}$ \\
\hline $\begin{array}{l}\text { Non-chest, non-genital } \\
\text { surgery }\end{array}$ & & $\begin{array}{l}\text { Facial feminization surgery, voice } \\
\text { surgery, thyroid cartilage reductions, } \\
\text { hair transplant }\end{array}$ \\
\hline
\end{tabular}

\begin{tabular}{|l|l|}
\hline Table 4. Recommended content of the referral letters for GAS surgery \\
\hline Patient characteristics & General identifying characteristics \\
\hline Psychosocial assessment & Results of the assessment and any diagnoses \\
\hline Duration of relationship & $\begin{array}{l}\text { Duration of the mental health professional's relationship with the } \\
\text { patient } \\
\text { Includes type of evaluation, and therapy or counselling }\end{array}$ \\
\hline Criteria for surgery & $\begin{array}{l}\text { Explanation that the criteria for surgery have been met } \\
\text { Brief description of the clinical rationale for supporting the } \\
\text { patient's request for surgery } \\
\text { Statement that informed consent (for sharing health information, } \\
\text { referral) has been obtained from the patient }\end{array}$ \\
\hline Informed consent & $\begin{array}{l}\text { Statement that the mental health professional is available for } \\
\text { coordination of care and welcomes a phone call to establish this }\end{array}$ \\
\hline Coordination of care
\end{tabular}




\begin{tabular}{|c|c|c|c|}
\hline Surgery & Complication & Presentation & Treatment \\
\hline \multicolumn{4}{|c|}{ Vaginoplasty $^{18,19}$} \\
\hline & $\begin{array}{l}\text { Hypergranulation } \\
\text { tissue }\end{array}$ & $\begin{array}{l}\text { Vaginal bleeding } \\
\text { Vaginal discharge } \\
\text { Pain/ irritation }\end{array}$ & $\begin{array}{l}\text { Silver nitrate application } \\
\text { Cauterization of tissue } \\
\text { Topical steroids }\end{array}$ \\
\hline & Neo-vaginal stenosis & $\begin{array}{l}\text { Vaginal pain } \\
\text { Inability dilating }\end{array}$ & $\begin{array}{l}\text { Dilation } \\
\text { Surgical repair }\end{array}$ \\
\hline & $\begin{array}{l}\text { Urethral stricture or } \\
\text { redundant penile } \\
\text { tissue obstruction }\end{array}$ & $\begin{array}{l}\text { Lower urinary tract } \\
\text { symptoms } \\
\text { Urinary retention }\end{array}$ & $\begin{array}{l}\text { Cystoscopy, urethral } \\
\text { dilation, reconstructive } \\
\text { surgery }\end{array}$ \\
\hline & $\begin{array}{l}\text { Rectovaginal/ } \\
\text { vesicovaginal fistula } \\
\text { (immediate or } \\
\text { delayed) }\end{array}$ & $\begin{array}{l}\text { Vaginal drainage/ } \\
\text { incontinence, } \\
\text { infection }\end{array}$ & Surgical repair \\
\hline & $\begin{array}{l}\text { Anorgasmia/sexual } \\
\text { dysfunction }\end{array}$ & & $\begin{array}{l}\text { Education } \\
\text { Pelvic physio }\end{array}$ \\
\hline & $\begin{array}{l}\text { Vaginal discharge } \\
\text { (E.g. Yeast, STI, } \\
\text { Folliculitis from } \\
\text { retained hairs) }\end{array}$ & $\begin{array}{l}\text { Bothersome } \\
\text { discharge, needing to } \\
\text { wear a pad }\end{array}$ & $\begin{array}{l}\text { Treat origin } \\
\text { If unknown cause: } \\
\text { Trials of topical } \\
\text { metronidazole, review } \\
\text { vaginal hygiene practices }\end{array}$ \\
\hline & $\begin{array}{l}\text { Pelvic floor } \\
\text { hypertonicity }\end{array}$ & Painful dilations & Pelvic floor physiotherapy \\
\hline & $\begin{array}{l}\text { Wound separation } \\
\text { (frequently to } \\
\text { posterior forchette) }\end{array}$ & $\begin{array}{l}\text { Typically, within the } \\
\text { first } 3 \text { post-operative } \\
\text { months will have } \\
\text { bleeding, discharge } \\
\text { and pain }\end{array}$ & $\begin{array}{l}\text { Education re: wound care } \\
\text { principles } \\
\text { Ensure continuous dilation }\end{array}$ \\
\hline \multicolumn{4}{|c|}{ Metoidioplasty and phalloplasty ${ }^{22,23,26}$} \\
\hline & Urethral stenosis & $\begin{array}{l}\text { Urinary symptoms, } \\
\text { retention }\end{array}$ & $\begin{array}{l}\text { Catheter drainage (for acute } \\
\text { retention) } \\
\text { Dilation } \\
\text { Surgical reconstruction } \\
\end{array}$ \\
\hline & Fistula & Incontinence & Surgical reconstruction \\
\hline & $\begin{array}{l}\text { Necrosis of the } \\
\text { neophallus (partial or } \\
\text { complete) }\end{array}$ & Pain, skin changes & $\begin{array}{l}\text { Control infection } \\
\text { Debridement } \\
\text { Surgical reconstruction }\end{array}$ \\
\hline & $\begin{array}{l}\text { Retained vaginal } \\
\text { mucosa/ } \\
\text { collection/cyst }\end{array}$ & Pain, discharge & $\begin{array}{l}\text { Drainage, surgical } \\
\text { reconstruction, observation }\end{array}$ \\
\hline
\end{tabular}




\begin{tabular}{|l|l|l|l|}
\hline & Anorgasmia & $\begin{array}{l}\text { Lack of erogenous } \\
\text { sensation }\end{array}$ & $\begin{array}{l}\text { Observation, medical } \\
\text { therapy }\end{array}$ \\
\hline & $\begin{array}{l}\text { Penile or testicular } \\
\text { implant erosion or } \\
\text { infection }\end{array}$ & $\begin{array}{l}\text { Pain, fever, exposed } \\
\text { implant }\end{array}$ & $\begin{array}{l}\text { Antibiotics and implant } \\
\text { removal }\end{array}$ \\
\hline $\begin{array}{l}\text { Urinary tract } \\
\text { infection }\end{array}$ & $\begin{array}{l}\text { Dysuria, acute lower } \\
\text { urinary tract } \\
\text { symptoms }\end{array}$ & $\begin{array}{l}\text { Antibiotics, rule out } \\
\text { anatomic cause }\end{array}$ \\
\hline
\end{tabular}

